\title{
THE TRADITIONAL AND ELECTRONIC STUDY RESOURCES TO THE TOPICS OF LINEAR ALGEBRA
}

\section{Dana ORSZÁGHOVÁ}

\begin{abstract}
In the paper we deal with actual topic of the didactic research in the theory of education that includes the application of IT tools in the modern mathematics teaching and in the individual study. Chapters on linear algebra belong to the important parts of the compulsory mathematical subjects. We focused on this mathematical topic and present what kinds of traditional and electronic study resources can use students of the Slovak University of Agriculture in Nitra in their study. In the next section it is presented an overview of study results in the first year of the bachelor study at the Faculty of Economics and Management, which is an indicator of the quality of the mathematics education.
\end{abstract}

Key words: teaching of mathematics, linear algebra, test results, electronic study materials, LMS MOODLE.

\section{TRADIČNÉ A ELEKTRONICKÉ ŠTUDIJNÉ ZDROJE K TÉMAM LINEÁRNEJ ALGEBRY}

Resumé: V príspevku sa venujeme aktuálnym otázkam výskumu v teórii vyučovania, ku ktorým patrí uplatňovanie nástrojov informačných technológií $\mathrm{v}$ modernom vyučovaní matematiky a v samostatnom štúdiu. K preberaným témam v povinných matematických predmetoch patria aj kapitoly z lineárnej algebry. Zamerali sme sa na túto čast' matematiky a prezentujeme, aké tradičné a elektronické študijné zdroje študenti používajú na Slovenskej pol'nohospodárskej univerzite v Nitre. Ďalej uvádzame prehlad študijných výsledkov na skúške v prvom ročníku bakalárskeho na Fakulte ekonomiky a manažmentu, ktoré sú jedným z ukazovatel’ov kvality matematického vzdelávania.

Klíčová slova: vyučovanie matematiky, lineárna algebra, výsledky skúšok, elektronické vzdelávacie materiály, LMS MOODLE.

\section{1 Úvod}

Stále aktuálnou témou pedagogického výskumu je uplatnenie informačných technológií v univerzitnom matematickom vzdelávaní. Praktická realizácia on-line vzdelávacích kurzov je na Fakulte ekonomiky a manažmentu (FEM) Slovenskej pol'nohospodárskej univerzity (SPU) v Nitre podporovaná systémom LMS MOODLE. Uvedené vzdelávacie prostredie ponúka učitel'ovi - tvorcovi kurzu rôzne možnosti pre vytváranie študijných alebo testovacích modulov, ktoré svojím obsahom a formou pomáhajú zvyšovat' atraktívnost' matematického vzdelávania, motivujú záujem študentov o štúdium matematiky a podporujú ich vaktívnom a samostatnom štúdiu (5), (3).

Štúdium matematiky na ekonomických fakultách má za ciel' naučit' študentov teoretické princípy matematických metód, ktoré uplatnia v aplikovanej podobe. V riešení aplikovaných úloh a na grafickú interpretáciu získaných výsledkov môžeme použit' rôzne programy a softvéry. Napríklad vol'ne dostupný matematický softvér GeoGebra v sebe kombinuje a navzájom spája geometriu, algebru a matematickú analýzu (1). Významným ciel’om využivania informačných technológií v matematickom vzdelávaní je (okrem iného) poskytnutie rôznych možností pre modernizáciu a zvyšovanie kvality štúdia nielen matematiky, ale aj iných študijných predmetov. Elektronické vzdelávanie poskytuje možnosti, ktoré môže pedagóg využit' na zvýšenie efektívnosti vzdelávania a na eliminovanie nedostatkov spojených s klasickým vyučovaním. Tradičné študijné zdroje $\mathrm{v}$ tlačenej podobe (napríklad učebnice, skriptá) sú v súčasnosti dopíňané študijnými materiálmi v elektronickej verzii, ktoré môžu mat' charakter povinnej alebo doplňujúcej a rozširujúcej študijnej literatúry $\mathrm{k}$ vybraným témam. Prostredníctvom nich môžeme zlepšit' motiváciu a záujem študentov o matematiku $\mathrm{v}$ teoretickej aj praktickej podobe (2).

\section{Obsahová náplň predmetu Matematika B a tradičné študijné materiály}

Hlavným zdrojom materiálu pre príspevok sú skúsenosti a poznatky $\mathrm{z}$ výučby povinných matematických predmetov $\mathrm{v} 1$. ročníku 
bakalárskeho stupňa štúdia na SPU v Nitre: Matematika A, Matematika B (denná a externá forma štúdia). V príspevku sme sa zamerali na tematickú oblast' Lineárna algebra, ktorá je vyučovaná $\mathrm{v}$ rámci predmetu Matematika B v letnom semestri. V tabul'ke č. 1 sú vybrané údaje o povinných predmetoch Matematika $\mathrm{A}$, Matematika B a počet študentov pre študijný program (ŠP) Účtovníctvo.

Tab. 1: Údaje k povinným predmetom Matematika A, Matematika B

\begin{tabular}{|c|c|c|c|c|}
\hline $\begin{array}{r}\text { Názov } \\
\text { predmetu }\end{array}$ & $\begin{array}{l}\text { Seme } \\
\text { ster }\end{array}$ & $\begin{array}{l}\text { Forma } \\
\text { štúdia }\end{array}$ & $\begin{array}{c}\text { Rozsah } \\
\text { prednášok/cvičení }\end{array}$ & $\begin{array}{l}2009 / 2010 \\
2010 / 2011\end{array}$ \\
\hline \multirow[b]{2}{*}{ Matematika A } & \multirow[b]{2}{*}{ zimný } & denná & $2 \mathrm{~h} / 2 \mathrm{~h}$ týždenne & \multirow{2}{*}{$\begin{array}{c}\text { Počet } \\
\text { študentov } \\
\text { ŠP } \\
\text { Účtovníctvo }\end{array}$} \\
\hline & & externá & $\begin{array}{l}10 \mathrm{~h} / 10 \mathrm{~h} \mathrm{za} \\
\text { semester }\end{array}$ & \\
\hline \multirow[b]{2}{*}{ Matematika B } & \multirow[b]{2}{*}{ letný } & denná & $2 \mathrm{~h} / 2 \mathrm{~h}$ týždenne & 74 \\
\hline & & externá & $\begin{array}{l}\text { 10h/10h za } \\
\text { semester }\end{array}$ & 40 \\
\hline
\end{tabular}

Do obsahovej náplne predmetu Matematika B patria tieto tematické okruhy:

- neurčitý integrál funkcie jednej reálnej premennej,

- určitý integrál funkcie jednej reálnej premennej,

- lineárna algebra (vektory, matice, determinanty, sústavy lineárnych rovníc)

- teória pravdepodobnosti.

$\mathrm{K}$ tradičným študijným materiálom na vysokej škole patria učebnice a skriptá. Učebnica Matematika a jej aplikácie (4) je určená pre študentov všetkých fakúlt SPU v Nitre. Obsah učebnice je rozdelený do deviatich kapitol, v teoretickej časti každej kapitoly sú vysvetlené pojmy a uvedené matematické vety a tvrdenia $\mathrm{s}$ dôkazmi, obrázky, grafy a tabul'ky. V praktickej časti každá podkapitola obsahuje ukážky príkladov, pričom aplikovaným úlohám je vždy venovaná samostatná podkapitola. Každá kapitola končí zadaniami a úlohami s výsledkami, ktoré sú hlavným obsahom praktických cvičení a slúžia aj na samostatné štúdium a overovanie získaných vedomostí.

3 Elektronické študijné zdroje a kurzy z matematiky vytvorené $v$ LMS MOODLE

Katedra matematiky FEM SPU v Nitre sa tvorbe elektronických študijných materiálov systematicky venuje. Prvé verzie elektronických kurzov boli vytvorené pre študentov v dištančnej forme štúdia. Externé formy štúdia majú nízku výmeru hodín kontaktnej výučby, preto sa $\mathrm{k}$ tlačeným študijným materiálom vytvárali aj elektronické zdroje, ktoré obsahovali okrem príkladov a úloh aj zadania seminárnych prác a ukážky testov na skúšku. V prostredí LMS MOODLE boli vytvorené kurzy aj pre študentov dennej formy štúdia (6), (7) 


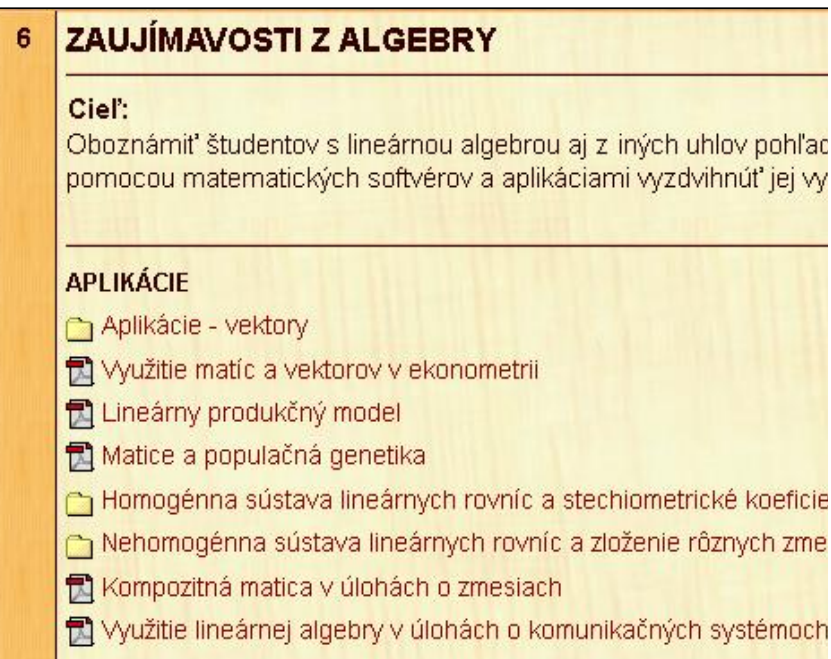

Obr. 1: Ukážky k téme „Zaujímavosti z algebry“

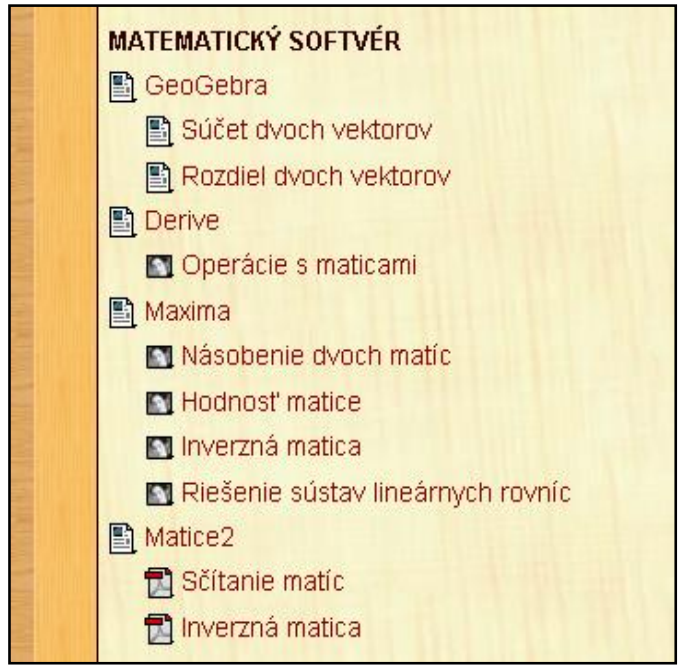

Obr. 2: Matematické softvéry - ukážky
Kurz Lineárna algebra (8) bol vytvorený $\mathrm{v}$ rámci riešenia projektu KEGA MŠ SR č. 3/7382/09 Teoretická a edukačná transformácia matematického vzdelávania pol'nohospodárskych inžinierov a má nasledovnú štruktúru:

- Teória - obsahuje elektronické učebnice a prednášky, cielene vytvorené pre študentov SPU

- Príklady - táto čast' obsahuje vzorové príklady s podrobným postupom riešenia

- Úlohy - sú tu materiály na opakovanie a preverovanie vedomostí z lineárnej algebry
- Testy - študenti si môžu overit' nadobudnuté vedomosti

- Seminárna práca - obsahuje on-line zadania seminárnych prác

- Zaujímavosti $z$ algebry - táto čast' obsahuje aplikácie, matematický softvér, články a internetové odkazy (Obr. 1, Obr. 2).

4 Systém hodnotenia študentov a prehl'ad výsledkov skúšok

Predmet Matematika B má nasledovný systém hodnotenia: počas semestra píšu študenti dva priebežné testy a odovzdávajú seminárnu prácu (za tieto aktivity môžu získat' 40 bodov) a následne absolvujú skúšku vo forme písomného testu za 60 bodov.

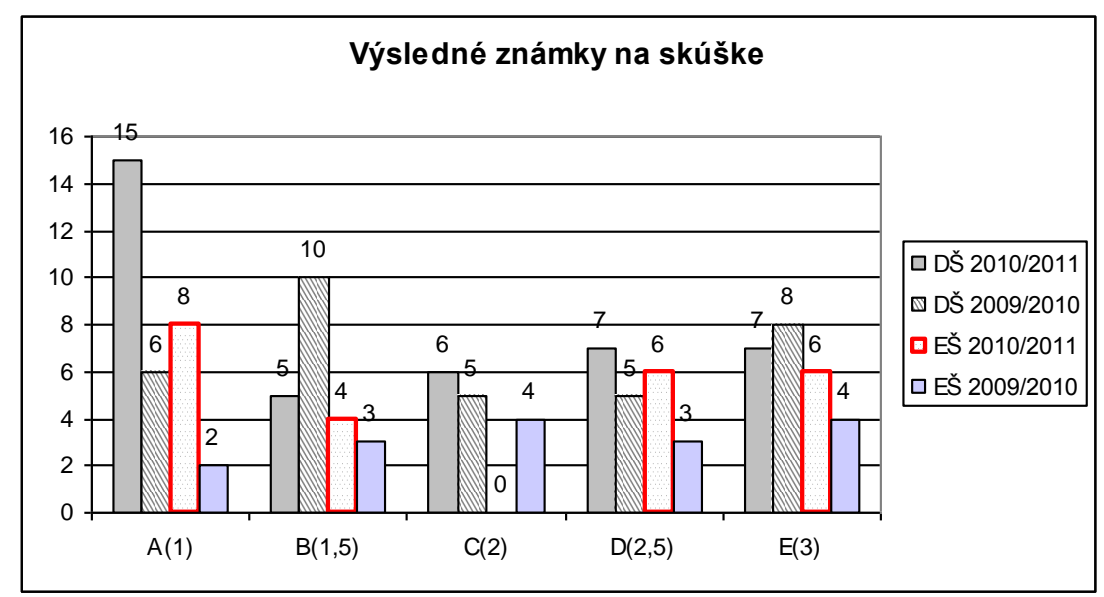

Graf 1: Výsledky skúšok z predmetu Matematika B (roky 2009/2010, 2010/2011)

V grafe č. 1 sú zobrazené výsledné známky na skúške $\mathrm{z}$ uvedeného predmetu Matematika B v akademických rokoch 2009/2010 a 2010/2011. Výsledky skúšok sú hodnotené štandardnou stupnicou $\mathrm{A}(1), \mathrm{B}(1,5), \mathrm{C}(2), \mathrm{D}(2,5), \mathrm{E}(3)$, FX(4). Zaoberali sme sa len výsledkami pre študijný program Účtovníctvo - denné štúdium (DŠ), 74 študentov, Účtovníctvo - externé štúdium (EŠ), 40 študentov. V tabul'ke č. 2 sú uvedené priemerné známky podl'a jednotlivých foriem štúdia. 
Tab. 2: Priemerné známky v jednotlivých akademických rokoch

\begin{tabular}{|c|c|c|}
\hline $\begin{array}{c}\text { Priemerná } \\
\text { známka }\end{array}$ & $2010 / 2011$ & $\begin{array}{c}2009 / 201 \\
0\end{array}$ \\
\hline DŠ & 1,825 & 1,985 \\
\hline E $\breve{~}$ & 1,985 & 2,125 \\
\hline
\end{tabular}

\section{Záver}

V príspevku sme prezentovali používané študijné materiály (tlačené aj moderné elektronické kurzy) a spracovali sme výsledky skúšok pre študijný program Účtovníctvo na SPU v Nitre. Z porovnania výsledkov vyplýva, že v akademickom roku 2010/2011 dosiahli študenti lepšiu priemernú známku z predmetu Matematika B v oboch formách štúdia - dennej aj externej. Prijímacie skúšky z matematiky na SPU v Nitre nie sú povinné, preto predpokladáme, že okrem iných faktorov aj dostupnost' študijnej literatúry (či už v tradičnej tlačenej alebo v elektronickej verzii) pomohla študentom v príprave na skúšku. Naučit' študentov, ako majú samostatne študovat' predmet s využitím odbornej literatúry, patrí $\mathrm{k}$ dôležitým podmienkam pre úspešné štúdium na univerzite.

\section{Literatúra}

[1] DRÁBEKOVÁ, J. Vizualizácia riešení vybraných ekonomických úloh pomocou softvéru GeoGebra. In Zborník príspevkov Teoretická a edukačná transformácia matematického vzdelávania. Nitra, SPU, 2011, s. 45-50. ISBN 978-80-552-0604-2.

[2] GREGÁŇOVÁ, R. Elektronické vzdelávacie materiály o Eulerovom čísle $e$. In 6 . konference o matematice afyzice na vysokých školách technických: zborník príspevkov z vedeckej konferencie s medzinárodnou účast'ou. Brno: Univerzita obrany, 2009, s. 95- 99. ISBN 978-807231-667-0.

[3] GREGÁŇOVÁ, R. Kurzy v prostredí LMS Moodle - prostriedok e-vzdelávania v matematike. In Trendy ve vzdélávaní 2009: zborník vedeckých prác z medzinárodnej vedecko-odbornej konferencie [CD-ROM]. Olomouc: Votobia, 2009, s. 428-431. ISBN 97880-7220-316-1.

[4] ORSZÁGHOVÁ, D. a kol. Matematika a jej aplikácie. Nitra, SPU, 2010, s. 376, 1. upravené a doplnené vydanie. ISBN 978-80-552-0479-6.

[5] ORSZÁGHOVÁ, D. Uplatnenie LMS MOODLE v štúdiu matematiky. In: UNINFOS 2011, zborník príspevkov z konferencie s medzinárodnou účast'ou (CD-ROM). Prešov: Prešovská univerzita v Prešove, 2011, s. 121-125. ISBN 978-80-970790-0-0.

[6] URL:

http://moodle.uniag.sk/fem/course/view.php?id= 44

[7] URL:

http://moodle.uniag.sk/fem/course/view.php?id= 143

[8] URL:

http://moodle.uniag.sk/fem/course/view.php?id= 207

Lektorovala: doc. RNDr. Zuzana Hlaváčová, CSc.

Príspevok vznikol s finančnou podporou projektu KEGA č. 021SPU-4/2011: Vyučovanie matematiky $s$ aplikáciami obsahové zmeny $v$ univerzitnom matematickom vzdelávaní.

Dana Országhová, doc. RNDr. CSc., Katedra matematiky, Fakulta ekonomiky a manažmentu SPU v Nitre, Tr. A. Hlinku 2, 94976 Nitra, SR, tel. 00421376414181 , e-mail: dana.orszaghova@uniag.sk 